\title{
6 Weathering the storm
}

\section{Reflections on a community- based approach to flood-risk management in Kumasi, Ghana}

\author{
Divine Ahadzie, Irene-Nora Dinye, \\ and Rudith Sylvana King
}

\section{Introduction}

The Intergovernmental Panel on Climate Change has identified sub-Saharan Africa (SSA) as one of the world's regions most vulnerable to the effects of climate change (IPCC, 2007; Serdeczny et al., 2015; Chirisa et al., 2016; Mail\&Guardian, 2018; IPCC, 2018). Although climate vulnerability translates into altered environmental conditions that increase weather-related risks to human settlements and infrastructure (IPCC, 2013), there has been limited research on climate adaptation in African cities (Magadza, 2000; Filho et al., 2018). Moreover, the policy directives and discussions that do exist to help vulnerable urban communities in SSAcountries continue to focus largely on mitigation rather than adaptation (Muller, 2007; Jagers \& Duus-Otterström, 2008; van Vuuren et al., 2011). While mitigation efforts focusing on the drivers of climate change are critical, the conversation on adaptation requires further attention (Muller, 2007). Adaptation models that deal with perceptions, social responsibilities, and appropriate community-based public relations interventions can be decisive in helping vulnerable communities improve their responses to flooding (Mullins \& Soetanto, 2011; Kellens et al., 2013; Kruse et al., 2017).

In many African countries, there is limited state capacity to address infrastructure deficits and socioeconomic challenges. In such cases, innovative and collaborative approaches to urban risk management response are vital. An example is the flood-risk management paradigm integrating social cohesion and community preparedness methodologies (cf. Kellens et al., 2013; Kruse et al., 2017). While such methods recognize the importance of the human dimension in creating resilient communities in a flood-risk management context, there is a need to better understand the specific interventions or actions that help communities integrate and utilize the existing knowledge, perceptions, and values that are key to a community-based flood-risk management approach (Wood et al., 2012; Chong et al., 2018). This work aligns with the Africa Climate Resilient Infrastructure Summit (ACRIS II), held in Addis Ababa from 20-21 April 2015, which emphasized the development of resilient communities as a priority in African urban disaster-management work (see also Sylla et al., 2016). 
Global development frameworks such as the Sustainable Development Goals (SDGs) also stress the importance of community resilience with a specific target, as part of the stand-alone urban SDG 11 (cf. Parnell, 2016). This focuses on the need to 'increase the number of cities and human settlements adopting and implementing integrated policies and plans towards inclusion, resource efficiency, mitigation and adaptation to climate change, resilience to disasters, and develop and implement, in line with the Sendai Agreement for Disaster Risk Reduction, holistic disaster risk management at all levels' (SDG target 11.b; see also Rodriguez et al., 2018).

This chapter aims to add to this conversation by understanding how communities at high risk of flooding perceive their own adaptive preparedness within a sub-Saharan West African context. The purpose therefore was to analyse the level of awareness of communities to current flood-risk management issues, and also understand the state of citizens' participation in seeking to proactively and collectively build a resilience spirit towards flood hazards. Through a co-production process to develop engagement strategies, the community showed keen interest and participated expressly in the series of engagements. It was further observed that being part of the data gathering process made it more acceptable to community members to appreciate and associate with the project.

The chapter begins with an overview of flood risk in Ghana and various frameworks for risk management, after which we introduce the research site of SepeBuokrom, and our CityLab approach to understanding community responses to the flooding risk in that community. After presenting our key findings, the chapter concludes with reflections on the enabling factors and challenges for knowledge co-production in this area.

\section{Managing flood risks}

In Ghana, as in many other SSA countries, flooding ranks highly among disasters in terms of casualties and property destruction. While the government is already overwhelmed in its attempts to tackle the hazard, the frequency and impacts of flooding have increased. Records from 1990 to 2015 indicate that flooding in Ghana killed over 500 people, affecting more than 4 million, and causing economic losses of roughly US\$800 million (Asumadu-Sarkodie et al., 2015).

Most of the existing measures employed to control flooding are structural in nature and have achieved little in terms of mitigation (e.g., river dredging, desilting, and the construction and rehabilitation of primary drains). Severe loss and damage continue, with property in the Accra metropolis worth US\$43 million lost due to flooding in 2009, an amount that increased to US\$150 million in 2011 (Frimpong, 2014). In June 2015, the International Federation of the Red Cross and Red Crescent Societies reported that flooding in Accra affected over 46,000 people, displaced 9,200 people, and resulted in over 200 deaths (IFRC, 2015). These numbers are unprecedented in Ghana's annals of flood disaster (ibid.). The trend in the ensuing years is indeed worrying. In March-June 2016, about 13 people died 
and 4,000 were displaced as a result of flooding (Nkrumah, 2016). In 2017, Ghana experienced widespread flooding, with five regions severely affected, devastating impacts to health, safety, property, and livelihoods, and about 1,500 people displaced to seek refuge in schools and churches (IFRC, 2017). In 2018, after just a few hours of rain, another devastating flood hit capital city Accra particularly hard, with images on social media showing streets submerged under one metre of water (Floodlist, 2018). In 2019, another flood hit seven of the country's traditional ten ${ }^{1}$ regions, resulting in the drowning of 12 children in the middle of the country, 29 deaths in the Upper East region, and over 1,000 buildings destroyed (Floodlist, 2019).

These increasing and severe impacts of flooding across urban Ghana call for a new integrated approach to tackling the risk, emphasizing considerations that assist communities in 'living with the risk' rather than solely focusing on prevention (Proverbs \& Lamond, 2017). This new resilience paradigm for reducing flood risk has not been given due consideration in many SSA countries, either theoretically or practically, in terms of developing integrated community floodrisk management frameworks.

\section{Mitigation versus adaptation}

Adaptation requires that communities consciously leverage social responsibility to identify their exposure to flood hazards, and to proactively undertake actions that engender a response to those threats, including how to recover from an event, and perhaps more importantly, how to build resilience for sustainable development (Mullins \& Soetanto, 2011; Kruse et al., 2017; Chong et al., 2018). Drawing on grey and academic literature on adaptation at the city-scale level in developing countries, it is clear that changing environmental conditions are increasing the weather-related risks facing human settlements, including increasing flood hazards (Douglas et al., 2008; Proverbs, 2011; Huong \& Pathirana, 2013; Serdeczny et al., 2015).

As a strategy to handle weather-related risk, adaptation is achieving greater prominence, particularly as societies recognize the gravity of their vulnerability to the impact of flooding (cf. van Vuuren et al., 2011). Given the documented trend of increasing flooding and the challenges posed by this reality, the need for supporting, facilitating, and enhancing communities' adaptive capacities for sustainable development is clear (cf. Lwasa, 2010; Jones \& Boyd, 2011; Jha et al., 2012). In addition, developing country contexts of extreme vulnerability and weak structural and economic foundations require bespoke adaptation solutions (Mertz et al., 2009; Serdeczny et al., 2015; Chirisa et al., 2016).

Mitigation is about reducing the short-term impact of flooding, while adaptation focuses on learning to cope over the long-term with flooding (van Vuuren et al., 2011). While mitigation is critical, adaptation is also vital to help vulnerable communities better respond to the flooding that is happening and will continue to happen. Adaptation work concerns influencing perceptions and social responsibilities, and instigating appropriate public relation models for effective community 
engagement (cf. Mullins \& Soetanto, 2011; Kellens et al., 2013). As implied by Niehm et al. (2008), shifting values through influencing perceptions and social responsibilities engenders citizenry involvement and greater community ties (see also Shafer et al., 2007). Moreover, the literature suggests that the theoretical and practical basis of how communities adapt are both context-specific and functional within social limits (Adger et al., 2007, as cited in Wilby \& Keenan, 2012). That is, while mitigation may often lead to global and/or international prescriptions, adaptation is localized and often culturally sensitive, suggesting the need to understand the social context of the community engaged (van Vuuren et al., 2011; cf. Bender, 2008; Pohl et al., 2010).

To contribute to such an understanding, the Centre for Settlements Studies (CSS) at Kwame Nkrumah University of Science and Technology (KNUST) undertook a community engagement study in a flood-prone community in Kumasi, Ghana's second largest city. The research wing of the College of Art and Built Environment at KNUST, the CSS researches urban and rural interventions that address the socioeconomic and housing needs of disadvantaged communities and settlements. The CSS also provides outreach programmes and training in settlement development and management. Over the last decade, the Centre's research has been guided by the Millennium Development Goals (MDGs) and, more recently, the SDGs approach to human settlements. The aim of this community engagement study was to assess a community's appetite to participate in the development of a community resilience framework (CRF) for flood-risk management.

CRFs intend to help vulnerable communities identify ways to prepare for and also cope with the occurrence of present and future flood-hazard events. Cutter et al. (2008) propose the Disaster Resilience of Place (DROP) model, which factors in localized information around the vulnerability of communities, and is specific to natural hazards such as flooding. Renschler et al. (2011) espoused what they call the PEOPLES model: Population and Demographics, Environmental/Ecosystem, Organized Governmental Services, Physical Infrastructure, Lifestyle and Community Competence, Economic Development, and SocialCultural Capital. The PEOPLES Resilience Framework provides the foundation to integrate quantitative and qualitative models that measure systems' resilience against disasters. emBRACE is another CRF recently developed by a consortium of five European countries. The core domains of the emBRACE focus on conceptualizing community resilience of resources, capacities, actions, and learning. Chong et al. (2018) espouse a framework seeking to engender a spirit of community resilience towards flooding, and identify four conditions for communities to focus on as deliverables: securing basic needs, being able to adapt to change, minimizing vulnerabilities, and emerging from poverty. Further to this these four conditions, the authors emphasize the important contribution of institutions in assisting communities to execute well-prepared disaster-resilient frameworks, particularly relating to planning systems, and resilience initiatives in rural communities (Chong et al., 2018).

While these frameworks are all useful in their own right, it is agreed that any CRF will require further adjustments for different cultural backgrounds, hazard 
types, and sociopolitical contexts (cf. Renschler et al., 2011; Kruse et al., 2017; Chong et al., 2018). Developed mostly for advanced economies like those in Europe and Asia, these CRFs are thus not likely to be well-suited to the political and socioeconomic conditions of SSA. This suggests the importance of understanding the requirements of a suitable approach to engendering community resilience initiatives in the local context of SSA countries such as Ghana.

Given the looming threat that flooding poses to cities and conurbations in Ghana and the subregion, the CSS focused this study on understanding urban communities' perceptions of flood risk. The study also engaged communities on the need for adaptation to flooding based on social responsibility models and community-based initiatives. Our approach to this engagement centred around the use of a 'CityLab' approach, which sees stakeholders not only as subjects for data collection, but partners in knowledge production and critical in driving the research focus (Brown-Luthango, 2013; AURI, 2014; Patel et al., 2015). So far, the notion of co-production in Ghana has mainly been applied to research collaborations between the state and communities in the area of land and water management (McCusker \& Carr, 2006; Akaateba et al., 2018; Mangai \& de Vries, 2018). To our knowledge, this study represents the first effort to focus on the coproduction of knowledge to develop a framework for implementing communityled resilience and flood-risk management initiatives in SSA.

\section{Sepe-Buokrom}

The research site of Sepe-Buokrom is a flood-prone community in Kumasi, Ghana's second largest city. For the last decade, Kumasi has been at high risk from flooding, with over half the city currently flood-prone, including the selected study area. Located in West Africa's forest zone, Kumasi has a wet, semi-equatorial climate, with two distinct rainy seasons (June and September), which produce an annual average rainfall of $1,400 \mathrm{~mm}$. The mean annual temperature is $25.7^{\circ} \mathrm{C}$ and humidity ranges from $53 \%$ to $93 \%$.

According to the 2010 National Census, Kumasi's population was 2,035,064, with an annual population growth rate of 5.7\% (Ghana Statistical Service, 2012). Interpreting the trend in population increase, Owusu-Ansah (2016) observed that human activities relating to land use have intensified in Ghana's inner cities, spilling over into public parks and natural open spaces, including riparian areas and wetlands. This trend has led to increasing numbers of settlements on flood-prone terrain, large areas of land covered by impervious surfaces without sufficient drainage, and correspondingly increased volumes of runoff from precipitation (Afriyie et al., 2018).

Figure 6.2 illustrates the main flood-prone locations within Kumasi Metropolis, as well as the study area of Sepe-Buokrom, one of Kumasi's most vulnerable communities. Houses in Sepe-Buokrom settlement are largely constructed from cement and sand-block walls, and roofed with corrugated iron sheets. The structures are clustered together with little space between, and choked gutters and drains are also common. The major economic activities in Sepe-Buokrom are 


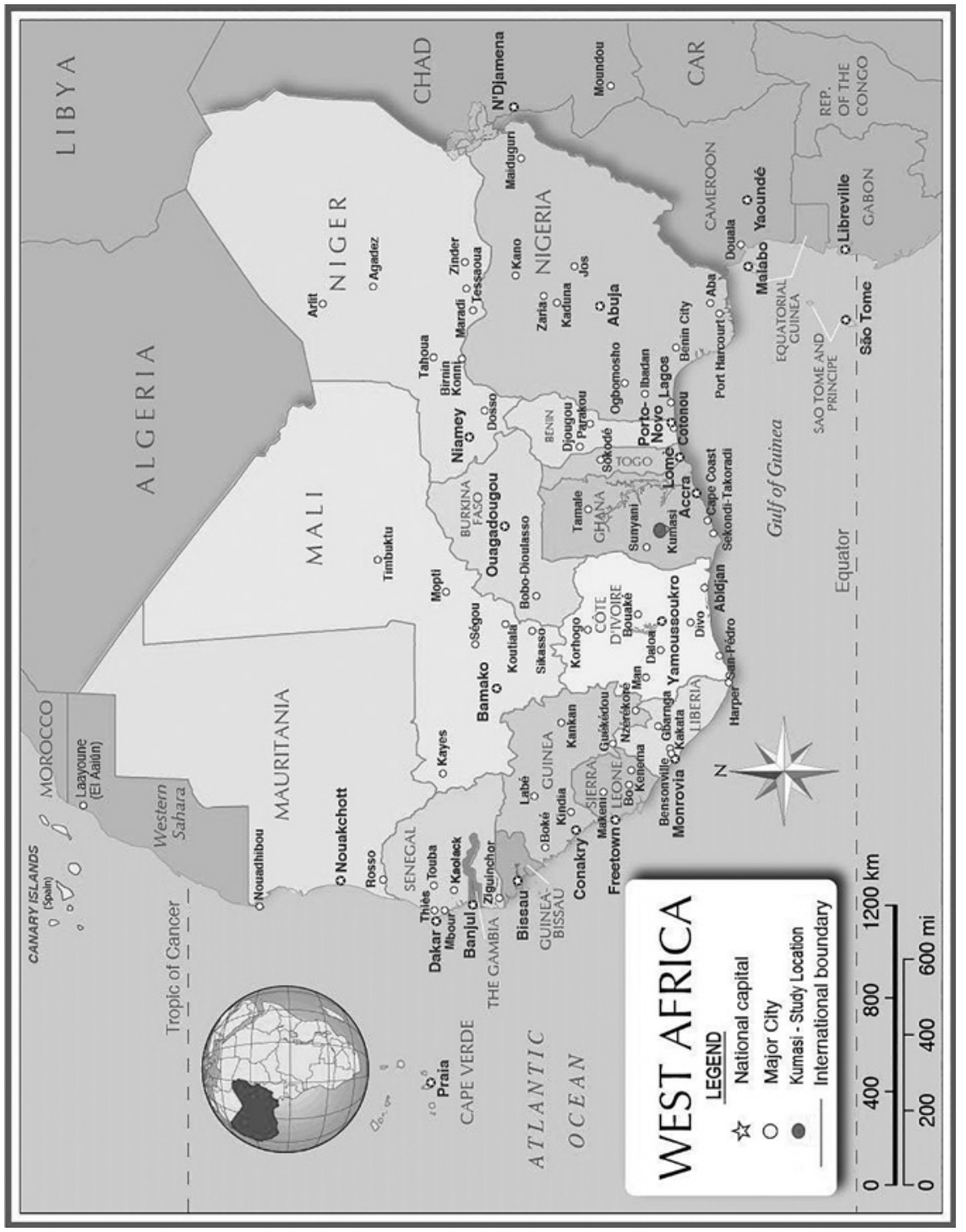

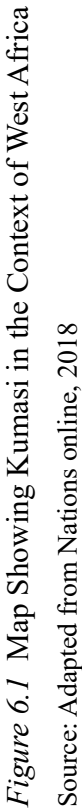



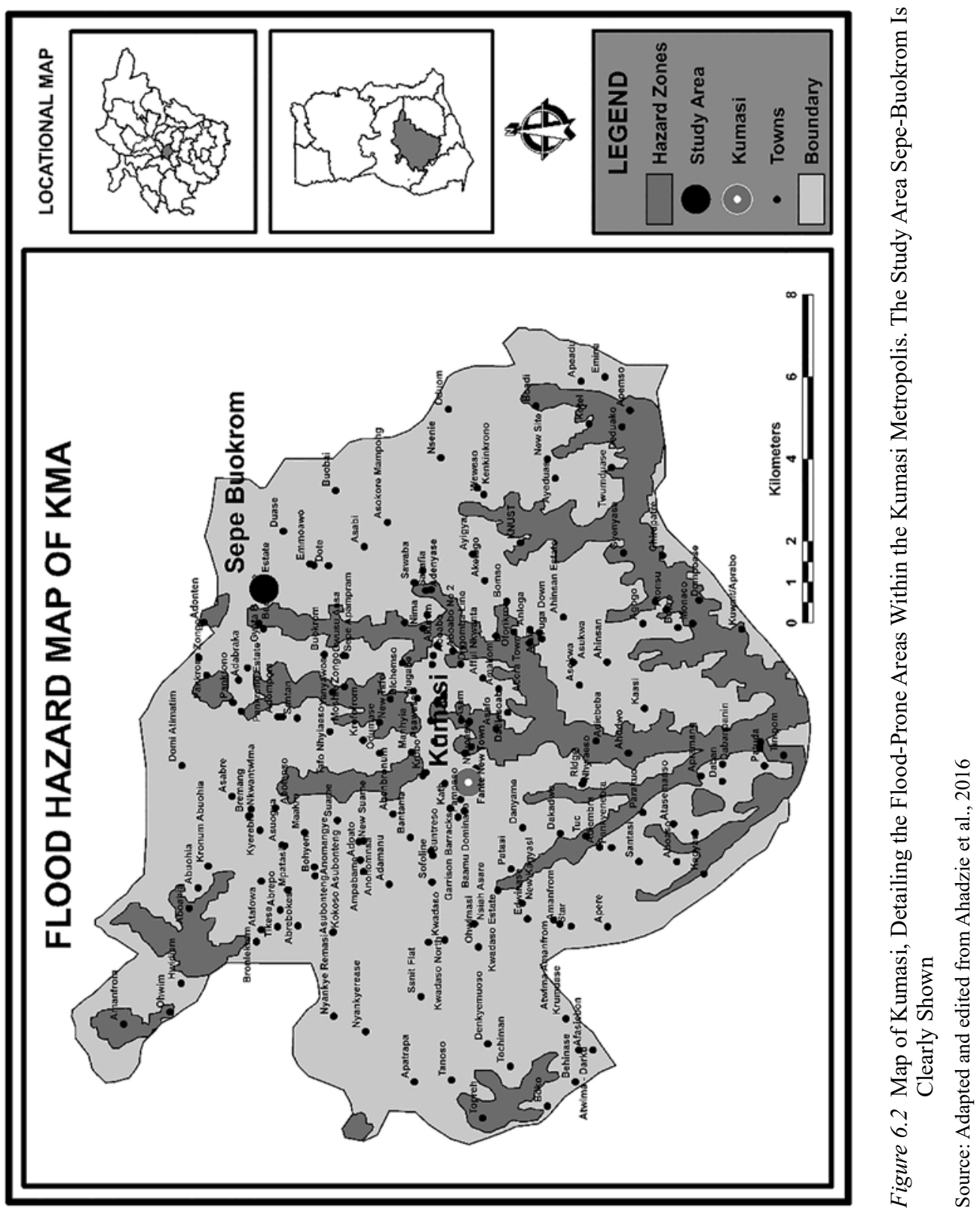
small-scale microenterprises such as petty trading, mechanical workshops, and carpentry workshops (Asamoah et al., 2016).

\section{Governance structure}

Located in the Ashanti region (one of Ghana's traditional ten administrative regions), Kumasi is governed by the Kumasi Metropolitan Assembly (KMA). The KMA is one of 260 Metropolitan/Municipal/District Assemblies (MMDAs), the highest unit of local government in Ghana. The KMA is headed by a Metropolitan Chief Executive (MCE), who acts in the same capacity as an executive mayor (GoG, 2016). Thus the MCE is a political leader from the ruling government, appointed by the President to oversee and act in his capacity to champion development at the local government level, as enshrined in the 1992 Constitution of Ghana and backed by Local Government Act 462, 1993.

Below the level of KMA, there are various sub-metros in Kumasi, ${ }^{2}$ including the Manhyia sub-metropolitan District Council, which includes the Buokrom Town Council, the body that oversees the community of Sepe-Buokrom (Figure 6.3). Like all the sub-metropolitan District Councils, the roles and functions of the Buokrom Town Council are stipulated under the Second Schedule of Legislative Instrument 2223 of 2015 (GoG, 2015). These functions include maintaining public spaces, waste management, and the administration of self-help projects (GoG, 2016), all of which are crucial in flood mitigation and adaptation efforts.

Sepe-Buokrom is an electoral area with its own elected assemblymen. Assemblymen (also known as assembly members) are elected local government officials within a community in the Metropolis/District, who represent their community at the District Assembly. Unlike members of parliament, assemblymen are apolitical.

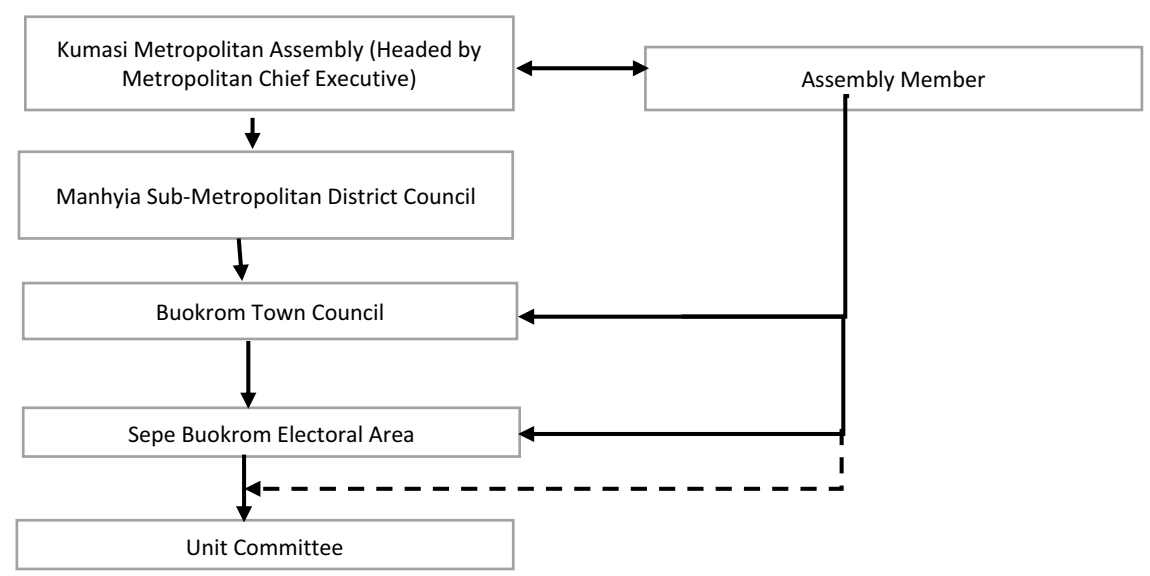

Figure 6.3 Local Governance Structure of the Kumasi Metropolitan Assembly Showing the Study Area, Sepe-Buokrom Electoral Area

Source: Authors 
Assemblymen are responsible for the articulation and realization of their constituents' aspirations. Most decisions in MMDA are subject to the approval of the assemblymen.

The Unit Committee is the smallest component of local government in Ghana. Unit committee members are also elected representatives who work with assembly members to enforce bylaws within their electoral/community level, as dictated by the MMDA. As the local government entity closest to the community, the Unit Committee (UC) plays important roles in enforcing bylaws and mobilizing resources. The UC also provides a structured mechanism of representation, participation, and accountability from the lowest community levels upwards. Together with the assembly members, UC members are responsible to the MMDA through the concerned Urban, Zonal, or Town Councils. However, UC members are not necessarily accountable to the assemblymen, as shown in the governance structure in Figure 6.3.

Given the complex and multi-layered nature of local governance, the project's data collection required not only identification of key informants, but also careful negotiation between all of these different actors. In the section that follows we present our research approach and methods.

\section{Research approach and methods}

In September 2017 the project commenced with a literature review to better understand the study's theoretical background and research area. An earlier study, Flood Risk Perception, Coping and Management in Two Vulnerable Communities in Kumasi, Ghana, which included a review of books, journals, newspapers, and grey literature conducted by the authors, greatly facilitated this process (Ahadzie et al., 2016). Evidence from this earlier study suggests that while flood-prone communities may be aware of the risk they are exposed to, there is no commitment to the community, community support, and/or sense of social responsibility towards engendering citizens' participation in flood-risk management.

We executed the project in three main phases as follows:

Phase One: A month of inception meetings to set the project goals, identify key stakeholders, and define the communication plan. The identification of key stakeholders from Sepe-Buokrom was an important element of this phase. Key stakeholders included the assemblyman, unit committee members, and opinion leaders. ${ }^{3}$ Once the stakeholders were identified, the research team began to build networks to assess stakeholder willingness and ability to participate in the project.

Phase Two: Data collection. The methodology was entirely qualitative, and included a mixture of segmented Focus Group Discussions (FGDs) and Stakeholder Meetings (SMs). In line with the CityLab approach, relationships were cultivated across institutions and interest groups to ensure broad participation. Five FGDs were held in total, followed by one SM. In all of these forums, we discussed participants' understandings of the causes of 
and potential solutions to flooding, and the potential role of communitybased initiatives to improve flood-risk management.

Phase Three: This final closure phase focused on completion of all research activities and validation of project data. This involved a second 'End of Project' SM, which attracted locally elected representatives (e.g., assemblymen), politically appointed government representatives (e.g., the MCE), and representatives from the National Disaster Management Organization (NADMO), the Environmental Protection Agency (EPA), as well as the media.

\section{Focus Group Discussions (FGD)}

The success of the FGDs was largely due to the involvement of the Sepe-Buokrom assemblyman and UC members, who mobilized and organized the community to participate. Enjoying a close relationship with the communities, the assemblyman and UC members have a strong grasp of local challenges. For brevity's sake, henceforth, 'assemblyman' will be used to refer to both the assemblyman and his UC members.

The FGD research team was comprised of a moderator, camera operator, recorder, and two secretaries (the secretaries took notes and observed the participants' general mood and body language). The venue for all the FGDs was the Sepe-Buokrom Town Council Building. For maximum participant involvement and understanding, the local language (Twi) was used as the medium of communication during all FGDs, which were held during the week of the 19-23 September 2017, and lasted approximately one hour per session.

The FGDs were organized with Men, Women, Children, the Youth, and Opinion Leaders, with all participants from the Sepe-Buokrom community. The first FGD was with Women (average age 47), who were mostly self-employed and engaged in livelihoods such as hair dressing and petty trading. The second FGD of Men mostly included traders and artisans (average age 59). The third FGD of Opinion Leaders included two women and five men, including teachers, traders, and pensioners. The fourth FGD of Youth included three females and three males (average age 25). The final FGD of Children included six girls and four boys (average age 13).

Each FGD session began with carefully selected videos of major flood disasters from across the world, including Ghana. Depicting the devastating and destructive nature of floods, they captured participants' attention, and in some cases, elicited strong emotions. The videos clearly made quite an impression on all participants, paving the way for what appeared animated and genuine engagements from participants.

Although community members were divided into groups based on gender and power in the community, hierarchies within these groupings still existed. For example, among the women were 'queen mothers' (female leaders in the communities), and among the men, representatives of the chief/chief linguist and the assemblyman (who have more power than other men in the communities) were 


\section{2}

present. However, the participants in all the FGDs appeared relaxed both before and during the discussions, and there were no signs of intimidation in any of the FGDs, with participants expressing themselves freely.

\section{Stakeholder Meetings (SM)}

Following the conclusion of the segmented FGDs, the research team conducted its analysis and facilitated two SMs, which included key urban stakeholders comprised of select residents, assemblymen, NADMO officials, and the media. Held five months apart, these SMs were used to discuss the study's preliminary findings, and also represented the first meetings specifically arranged (not only in Kumasi, but in all of Ghana) to discuss CRFs and how communities can respond to flood-related issues.

The first SM, which took place at the town council meeting in the SepeBuokrom community, attracted educators, religious leaders, unions, market/trader associations, opinion leaders, and representatives from traditional leadership (chiefs) (Figure 6.4). Despite asking the assemblyman to ensure a gender balance, the stakeholder groups composition was overwhelmingly male - females constituting just over one third of the participants - reflecting the male-dominated nature of Ghanaian culture, particularly in areas of decision-making.

The second SM was planned for April 2018. However, local elections held in the same period required the research team to delay the meeting until August 2018. The second SM included heavy representation from assemblymen, along with officials from the Kumasi Metropolitan Assembly (KMA), the National Disaster Management Organization (NADMO), and the media. Held at the KMA (the seat of the local government in Kumasi), the second SM was opened by the MCE,

\section{AFFILIATIONS OF PARTICIPANTS}

E Series 1

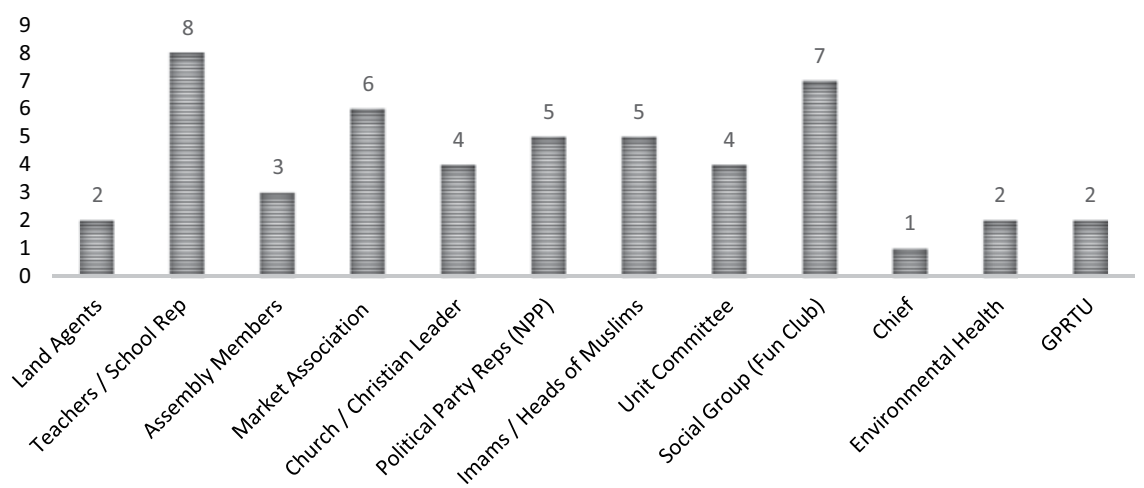

Figure 6.4 Participants' Affiliations in Second Stakeholder Meeting

Source: Authors 
whose participation spoke to the event's significance and government's interest in the discourse.

During his opening remarks, the MCE highlighted the increasing threat of flooding to the city in recent times, and assured government support for any floodrisk management initiative in the metropolis. Towards the end of the meeting, the MCE requested that the CSS research team join the KMA in preparing a proposal that will extend this type of stakeholder engagement to all MMDAs in the Greater Kumasi area, intimating that the KMA was ready to offer all the necessary support in facilitating these meetings.

\section{Data analysis}

Data analysis was undertaken in two stages. First, FGD data (in the form of notes, audio, and video) were transcribed from the local dialect, Asante-Twi, to English, with research assistants verifying the translations for validity. Thereafter, our senior researchers held a group meeting to go through the transcribed data again, using the audio and video versions to verify and validate that data.

We chose the qualitative data analysis (QDA) computer software package NVivo desktop, version 10.0 for its ability to accommodate numerous data formats in a single analysis (Dollah et al., 2017; Zamawe, 2015). Data was coded paragraph by paragraph, at multiple nodes, and analysed data were presented in the form of graphs, pictures, and the 'Word Cloud'. The Word Cloud was generated by running Word Frequency queries that identify key phrases within the data. Figure 6.5 depicts findings from Focus Group Discussions, using Word Cloud after the Nvivo analysis. The results visually depict the degree to which prominent personalities (assemblyman, chief, and MP) are expected to drive the common vision of the community towards achieving flood resilience.

Visually highlighting the relative frequency of words in a text, the Word Cloud offers a way to capture text responses from qualitative data using visual means to reflect insights drawn from peoples' social setting, background, and experience of socioeconomic issues (cf. Lohmann et al., 2015). As a form of analysis, Word Clouds have the marked advantages of being very fast and simple to conduct once the difficult work of transcribing has been done. The results of the analyses are also easy to comprehend and visually appealing, reveal only the essential variables, and provide a form of emotional connection that sets the tone for further discussions (McNaught \& Lam, 2010).

\section{Key findings}

This section provides the key findings from the FGDs and the SMs.

To evaluate our findings we used Norris et al.'s (2008) four primary 'community adaptive capacities': economic development, social capital, information and communication, and community competence. We also draw on Chong et al.'s (2018) position that the values and roles that institutions/agencies involved in disaster management bring on board are key in helping to build resilient communities. In 


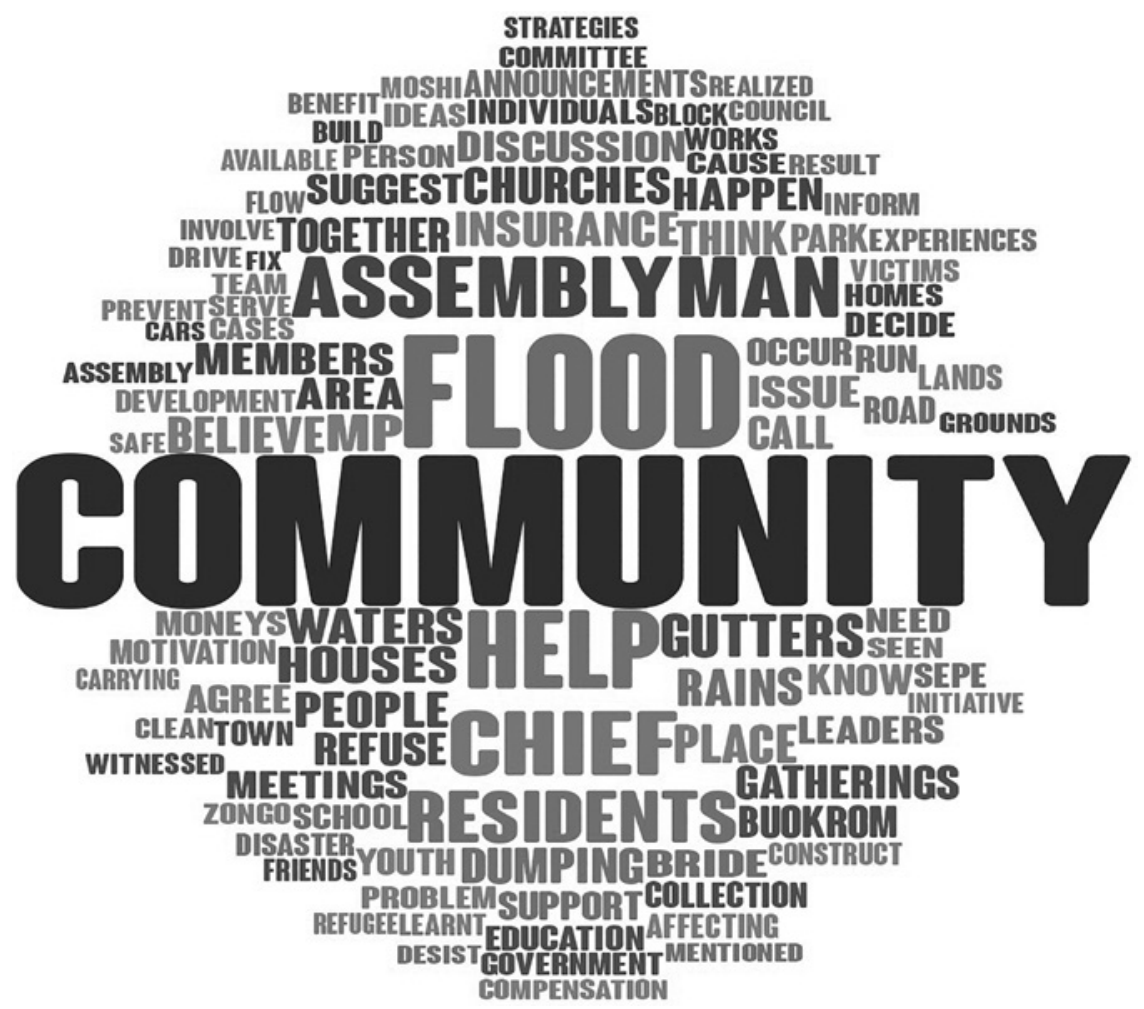

Figure 6.5 Word Cloud on Achieving Flood Resilience

Source: Authors

terms of economic development, the study revealed that, like many deprived communities in SSA countries, Sepe-Buokrom lacked the capacity or readiness to leverage economic resources to engender community resilience. Also, while social capital is deep-seated and used for individual mutual support (e.g., funerals), the community is yet to leverage this quality and apply it collectively in the interest of building a resilient communal spirit towards flood hazards. Regarding information and communication, within the community, access to and sharing of flood information is nonexistent, and there is no engagement on how to handle communication collectively during a flood disaster. Most flood victims we encountered at the FGDs intimated that the assemblyman would be the first point of contact in a crisis situation (via mobile phone), though this was based on individual intuition rather than being an official policy. Finally, while the community was aware of its extreme vulnerability to flooding, no attempts to build a community competence towards engendering adaptive capacities to flood hazards have been made. 
Through analysing the FGD and SM data, three main factors identified by participants as necessary to developing an urban CRF for flood-risk management emerged. These are: 1) the importance of local leadership; 2) residents' initiative; and 3) community commitment, loyalty, and togetherness. The importance of local leadership aligns with the CRF developed by Chong et al. (2018) for Malaysia, suggesting the value of institutions and the need to integrate their role. This is particularly the case for places like Sepe-Buokrom, where, as in many Ghanaian communities, sociopolitical circumstances have led to a lack of social responsibility, meaning communities will continue to rely on institutions while they work on developing community resilience initiatives towards flood hazards. However, Cutter et al. (2008) observe that financial considerations often make institutions reluctant to focus energy on communities' hazard vulnerability - a concern that also arose and is discussed further in the next sections. That said, we argue that the way forward involves building a common vision of leadership requirements, which are detailed next.

\section{Leadership is key}

The FGD data established that participants viewed strong collaboration between residents and the 'leadership trio' (i.e., assemblyman, ${ }^{4}$ chief, and MPs) as important to improving the community's ability to mitigate, prepare for, respond to, and recover more quickly from flood disasters. This echoes findings from a similar study conducted in the capital of the country, Accra, which found that while community leaders participated in the implementation of flood-risk management strategies, they were often not involved in the formulation of these strategies (Atanga, 2020). Considering the assemblyman's role and responsibility to consult and maintain close contact with his electoral area while also liaising between his people and the District Assembly on development issues, the study identified him as the best person to mobilize the community and initiate the community resilience approach. Per the Local Government Act, the assemblyman is to 'maintain close contact with his electoral area, consult his people on issues to be discussed in the District Assembly and obtain their views, opinions, and proposals; present the views, opinions, and proposals to the District Assembly; and meet with the electorate before each meeting of the Assembly' (Act 462, 1993).

It must be noted here that the role of the assemblyman at the local level in Ghana is similar to that of an MP at the national level. That is, he is expected to represent his peoples' views at the District Assembly, and to share Assembly decisions with his constituents. ${ }^{5}$ The District Assembly meanwhile exercises deliberative, legislative, and executive functions at the local government level, complementing the central government. Thus, District Assemblies are responsible for the overall development of local communities, and should promote and support relevant socioeconomic programmes. For example, the District Assemblies are expected to 'be responsible for the development, improvement, and management of human settlements and the environment in the district' (Act 462, 1993). ${ }^{6}$ This includes 
managing flood risks and other disasters to ensure properties and people are protected. The assemblyman is thus the community's elected representative tasked with carrying out such activities at the community level. However, unlike MPs, who are remunerated and can draw from the District Assembly Common Fund $(\mathrm{DACF})^{7}$ for developmental projects in their constituencies, assemblymen are neither remunerated for their services, nor can they directly access the DACF. The assemblymen receive some allowances for attending assembly meetings, and ex gratia after their tenure expires (a four-yearly cycle). In other words, assemblymen rarely have the resources at their disposal to execute their mandate of ensuring that services are delivered at the local level efficiently and effectively (Abdallah, 2011).

According to our study, despite having the mandate and commanding the respect, the assemblyman felt incapable of mobilizing the community for meetings to discuss issues related to flood-risk management, or to undertake communal work to manage flood risk. Thus, our study revealed that although the zeal to work may exist, the assemblyman's inability to harness the resources to do that work disempowers the role. This is particularly undermining given that, according to the FGD data, the electorate's expectations of assemblymen are very high, in spite of the assemblymen's frequent inability to deliver. Adequately resourcing assemblymen therefore could empower and enable them to carry out their mandate.

Unlike the assemblymen, the MP was seen by FGD participants as able to access the resources needed to promote community resilience. That is, the MP can ensure that communities in flood-prone areas receive a share of the DACF to promote CRF activities. The FGD participants also identified traditional leadership (the chief) as key to the promotion of a CRF. As a respected and influential person who occupies the role of community custodian, the chief's participation in resilience efforts was deemed critical.

Thus, the importance of these three key stakeholders working together to promote community resilience to flood risk through a common vision came through strongly from the FGDs. Table 6.1 shows some of the striking comments emerging from the FGDs around the 'Leadership is Key' sub-themes (e.g., role of the key personalities and residents).

\section{Residents initiative}

The second major finding from the FGD data analysis was the need for individual households to participate in community-based initiatives to help promote a CRF. FGD participants identified two ways for households to do this. First, ensuring proper disposal of refuse, and second, fully committing to any flood-management initiatives undertaken in the community.

\section{Commitment, loyalty, and togetherness}

The third and final element needed to facilitate community flood-risk resilience was articulated as a combination of 'commitment, loyalty, and togetherness'. The 
Table 6.1 Emergent themes and supporting notable comments from FGDs

\begin{tabular}{|c|c|}
\hline Themes and sub-themes & Example of survey response \\
\hline Leadership is key & $\begin{array}{l}\text { As my colleagues have already mentioned, the core } \\
\text { members of the leadership are the assemblyman, the } \\
\text { MP, and the chief. If these three come together and } \\
\text { mobilize and educate the youth and the elders of the } \\
\text { community, there is no way the community would not } \\
\text { get involved. }\end{array}$ \\
\hline $\begin{array}{l}\text { a Role of the } \\
\text { assemblyman }\end{array}$ & $\begin{array}{l}\text { I believe all responsibilities lie on the assemblyman. He is } \\
\text { in the best position to identify the problems facing the } \\
\text { community. Hence, he should be the one to mobilize the } \\
\text { youth to take steps in fixing those problems. }\end{array}$ \\
\hline b The role of the chiefs & $\begin{array}{l}\text { The chief is the owner of the community. Without him } \\
\text { the assemblyman cannot work effectively. So, the chief } \\
\text { must be involved, together with his team. }\end{array}$ \\
\hline c The role of MPs & $\begin{array}{l}\text { Looking at our community now, the MP has played } \\
\text { very little role in the community's development. If the } \\
\text { assemblyman is to work and work effectively, it will be } \\
\text { upon the shoulders of the MP. }\end{array}$ \\
\hline d Role of residents & $\begin{array}{l}\text { It is therefore important for us the residents to maintain } \\
\text { and clean our homes and this will help prevent flooding }\end{array}$ \\
\hline
\end{tabular}

Source: Authors

shared commitment was expressed as a prerequisite for the community's successful undertaking of its own initiatives to reduce flood risk. This shared commitment and unified vision would need to be negotiated with an understanding of the community's history, conflicts, and shared future.

In contrast to the FGDs, the Stakeholder Meetings were focused on data validation and consensus building. The data from these meetings were analysed manually from written and summary reports and notes taken at the meetings (versus using Nvivo qualitative data analysis software, as was the case with the FGDs). The two SMs were also used to ascertain how well various stakeholders would take up the challenge to mobilize their respective communities to achieve the common vision relating to building a CRF for flood-risk management.

At the first SM, we presented themes that arose from the FGDs, asking participants the following questions:

- Were the FGDs adequately representative of the community?

- Did stakeholders agree that Sepe-Buokrom is a flood-prone area? How did they reach their conclusion?

- Have there been any other gatherings to discuss flooding issues within the community?

- What can communities do to lessen the immediate impact of flooding?

- Is there a safe haven in the community where people can assemble when flooding occurs? 
- Who would be the appropriate person/s to lead community-based resilience? - What can the community do to help the area leadership in controlling floods?

The participants affirmed that the demographic groupings used for the FGDs were exhaustive and adequately represented the community. Based on their experiences, they expressed overwhelming support for the notion that Sepe-Buokrom (the study area) is flood-prone. However, while participants accepted that their area is highly flood-prone, it emerged that this understanding has never caused them to engage with the risk factors in terms of how they as a community can engender their own resilience. Regarding the question of a safe haven, participants identified a school block, which they believe is located at the community's highest point. However, the idea that this school is 'safe' is based not on proven fact, but rather on an incident that occurred about a decade ago, when a message claiming that a meteorite was aimed to hit a location in Ghana went viral. The instinctive response of many residents in Sepe-Buokrom was to congregate at this particular school - which may or may not actually be located at the highest point. As a result, this location continues to register in peoples' minds as a rallying point in the event of flood emergency.

Results from the first SM also strongly confirmed support for the "leadership trio' of the assemblyman, the chief, and MP. Indeed, a participant specifically used the words 'Common Vision' (which originally came out of the FGD findings), which phrase has since been adopted by the research team, and could be used as a catchphrase to whip up public interest for the research findings. Participants further expressed their full support in rallying behind this leadership trio for any flood-risk management initiative. Based on this, we anticipate that stakeholders in any typical Ghanaian community would equally express similar willingness to collaborate.

It should be noted that the first SM in Sepe-Buokrom represented the first community platform where communities interrogated the idea that they can take responsibility for themselves to achieve flood-risk resilience. Going beyond the usual conversation that focuses only on the causes of flooding and government relief and support, this novel platform attracted publicity from electronic and print media in both the Kumasi Metropolis and across Ghana.

At the second SM, which was largely attended by assemblymen (Figure 6.6), the discussion focused on issues around how the assemblymen as elected community leaders regarded the community's expectation that the leadership trio (i.e., themselves, the MP, and chief) should initiate flood-risk management initiatives.

Manually analysing the data from this meeting, we divided the results into three thematic categories: 1) leadership for the common vision; 2) community role; and 3 ) the role of government institutions.

\section{Leadership for common vision}

Results highlighted issues around the expectation that the assemblyman should take the lead role in mobilizing and addressing community development, as such initiatives are often seen as threatening both to the MP's political career and to 


\section{Participants' Affiliations}

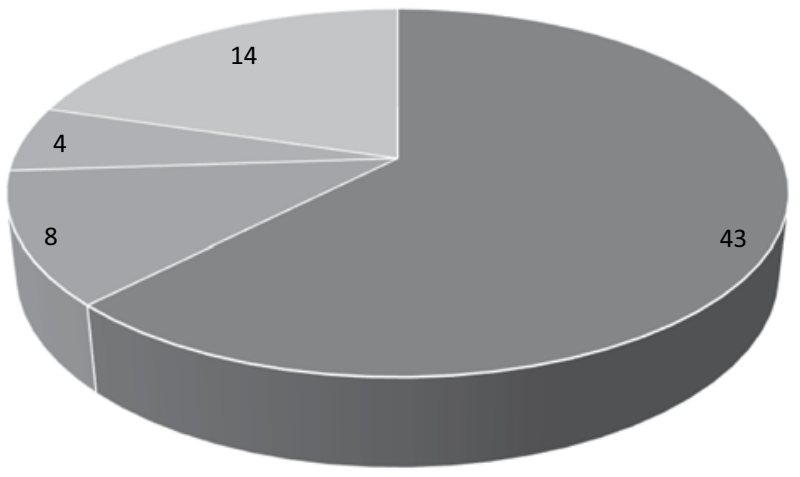

- Assembly members $\square$ KMA officials Nadmo officials $\square$ The press (radio, print, and TV media)

Figure 6.6 Participant Affiliations in the Second Stakeholder Meeting

Source: Authors

traditional authority. As a result, it is unlikely those latter two stakeholders will cooperate, for fear of being unseated. Similarly, the assemblymen also believed that the level of recognition they receive in the community can be perceived as undermining the chief's role, resulting in traditional leaders ignoring assemblymen's advice on land-use issues in particular. ${ }^{8}$ In other words, one of the key 'leadership trio' actors expected to drive the common vision expressed scepticism concerning their ability to play that role. It was therefore suggested that joint meetings of the leadership trio would be fundamental to driving any 'Common Vision'. Recommendations were also made for the Manhyia ${ }^{9}$ palace directorate to host similar forums and discussions. This could leverage support from the King of the Ashanti Kingdom (Ashanti Region of Ghana), and therefore from numerous chiefs, to delve deeper into these issues, particularly addressing the lack of collaboration between key role players.

While we expected the leadership trio to operate from a common vision on all aspects of community development, including flood-risk management, the feedback we received - at least from the perspective of the assemblymen contradicted this assumption. As previously noted, assemblymen lack direct access to funds that would allow them to take bold initiatives specific to their electoral areas. As such, it was suggested that an appeal be made to Parliament to review the allocation and use of the District Assembly Common Fund, to legally accommodate assemblymen. An alternative proposal was the establishment of an 'Assemblymen's Common Fund', to enable assemblymen to access resources for community development projects. 
Following the SMs, these issues continued to be discussed in the media, including suggestions that government should consider implementing a 5\% fund for assemblymen (Graphic Online, 2018). All of this shows the contribution coproduced research can make to the national discourse.

\section{The community role}

The role of communities was another key theme to emerge from the second SM. Participants expressed the belief that the spirit of social responsibility, which previously existed in Ghana's urban communities, needs to be reawakened. For instance, communal labour, which used to happen in most communities, no longer occurs. Most urban communities in Ghana today do not see communal labour or community and developmental challenges as their responsibilities, but rather those of the state and its agencies. Linked to community participation, stakeholders advocated for a scheme to train community-based volunteers in flood-risk management skills. These include but are not limited to pre-flood planning and flood clean-up. Participants also suggested training in the construction of simple flood defences; swimming and rescue measures; and preparation of flood-risk maps. Participants also discussed assemblymen's limited regulatory and enforcement authority when it comes to ensuring that communities adopt and adhere to resilience initiatives for flood management.

Currently Ghana lacks any Flood Control Act that could guide either Development Control Officers operations, or the specific roles and jurisdiction of assemblymen, including how they might enforce or regulate community-based flood-resilience activities. Participants indicated that if such a framework existed and informed community members of their rights and responsibilities when it came to flood resilience initiatives and actions, the people would play their part.

\section{The role of government institutions}

The last theme that emerged from the second SM was the role of government institutions in aggravating the flood problem. Specifically, respondents noted that development engineers and planners in local government departments contribute to the problem by approving permits for construction in low-lying areas susceptible to flooding. Respondents further indicated that the District Assembly itself refuses to act, even when such cases are reported by assemblymen or community members. These factors coupled with rent-seeking by government officials can result in permits being wrongfully allocated. The performance and ethics of local government officials were also discussed, followed by calls for appropriate penalties for officials found guilty of collusion with developers seeking to build in low-lying areas.

Data from the second SM also concluded that assemblymen needed to advocate harder for better collaboration between the various institutions (e.g., the NADMO, the Lands Commission of Ghana, the Engineers Unit of the Metro-works 
Department) at assembly meetings, in the interest of promoting community resilience. It appears that local government officials fail to fully recognize the importance of risk communication, which continues to be played down (cf. Ahadzie \& Proverbs, 2011), all of which reflects local government's relative weak appreciation for the importance of engaging communities in disaster risk management (cf. Terumoto, 2006; Chong et al., 2018).

\section{Reflections of the Kumasi CityLab}

This section highlights the reflexive discourse, examining the enablers of success for the community engagements, including the FGDs and SMs, as well as the challenges and prospects of promoting a CRF for flood-risk management.

\section{Enabling factors}

Previous CityLab experiences advocate for a good relationship and rapport between CityLab stakeholders (Patel et al., 2015). This is to engender trust and reciprocity, which are required for successful co-production of knowledge (ibid.). Fundamental to the success of the Kumasi CityLab project was our ability to identify key stakeholders, which was possible due to our prior engagements (e.g., with Sepe-Buokrom's assemblyman) and our development of new networks (e.g., with NADMO officials and the presiding member of the KMA). From the very onset, the project identified key actors (the assembly member and NADMO officials) with whom future partnerships were developed. The core principles underpinning these relationships were trust, transparency, embrace and respect for diversity, enhanced inclusivity, flexibility, and accessible communication.

The importance of taking the time to foster good relationships was seen in our research coordinator's engagement with the Sepe-Buokrom assemblyman. A continuation of the relationship we had developed with him due to a previous study in 2016 (see Ahadzie et al., 2016), this relationship played out over the course of preliminary meetings (in which we explained the purpose of the project, its benefits to the community, and the role he was expected to play in making the project a success), right through to the second SM in August 2018. The assemblyman's interest in the project came from a desire to find solutions to the serious problem of flooding confronting his constituency, the success of which also could win him more credibility and political visibility. This long-term process not only enabled support from the assemblyman and his unit committee (UC) members from the onset, but also helped put the community at ease, which translated into people willingly making themselves available to listen to our aims and objectives, and then participate in the study.

Although serving the same electoral area, the assemblymen and UC members generally operate independently of each other (Figure 6.3). If not carefully managed, this separation could create problems for community engagement project like ours. However, bringing both parties on board from the project's beginning 


\section{2}

led to one of the Kumasi CityLab's biggest findings, which is that to influence the level of community participation in flood-risk management and community-based resilience initiatives, early identification of and engagement with the assemblyman and his office as a key stakeholder are vital.

Due to the assemblyman's active participation, the research team was able to identify and mobilize participants for the Focus Group Discussions (FGDs) and the first Stakeholder Meeting (SM) at Sepe-Buokrom. Similarly, the researchers relied on the presiding member ${ }^{10}$ of the General Assembly to attract assemblymen to participate in the second SM in August. Our engagements with the presiding member took place in early July 2018 , and were made possible during prior relationship-building with the NADMO officials of the KMA.

Regarding NADMO, we found that recognition of NADMO's expertise was all the incentive needed to acquire their full participation in the project, which opened the way for frank discussions about the support and expertise they can offer towards developing a CRF. NADMO further helped to organize the second SM (where the NADMO Director of the KMA also made a presentation supporting the project). It is clear that NADMO now appreciates the need for bringing on board communities confronted with flood issues, and they have recently participated in radio discussions to whip up citizen participation for developing flood resilience. This recent sensitization effort is new, and could be attributed to the CityLab engagements discussed in this chapter.

In sum, our research team's outreach efforts with the community's assembly members and opinion leaders played a critical role in successfully securing participants for all sessions, and making the best use of those sessions. When planning the FGDs, the research team successfully identified participants' livelihood, sociodemographic, and economic situations within the various groupings so that our subsequent discussions on the impact of floods were relevant to participants' actual livelihoods, activities (in small-scale businesses or school), and gender issues. With this information in hand, the research team was better able to provide the most appropriate presentation to best engage with participants based on their individual situations, which was key to the success of the FGDs. For instance, based on what we knew about participants, we chose to show videos of flooding in Ghana and other parts of the world as part of the FGDs, which helped meet the needs of the varied stakeholders, including the schoolchildren (cf. Pasquali, 2007)

The primary aim of the Kumasi CityLab was to create a space for knowledgeexchange and experience-sharing between different stakeholders, with the further goal to produce knowledge that could serve to ignite continued collaboration between the different entities involved. Based on feedback from both the research team and CityLab participants, this objective was largely met. The research process provided a rich source of information about Sepe-Buokrom, uncovering important nuances, like the community's diversified nature based on ethnic lines, apparent tensions between two chiefs, and various perspectives on the potential for and challenges to successfully implementing a CRF for floodrisk management. 
Our research also proved the value of using an Audio-Visual presentation during all FGDs and SMs, given the extent to which it engaged participants' attention and sparked interest in the discussions that followed. In particular, participants at the first SM deeply appreciated the visuals showing how devastating the impact of flooding can be, and requested copies for further engagements in their respective constituencies. All of these engagements gave the research team much deeper insight both into how individuals cope with flooding, and how there is a lack of collective engagement in terms of addressing flooding issues at the community level.

Participants of both SMs also commended the CSS and its research team for hosting this series of community engagements to tackle the problem of flooding in Ghana. The presiding member commented that the CityLab approach diverts attention from the 'populist approach' favoured by government functionaries (e.g., ministers of state). Mainly focusing on (admittedly much-needed) relief items and structural demolition, that approach is viewed by many Ghanaians as motivated more by the desire to win political favour than it is to address the root causes of and problems resulting from flooding. Moreover, demolition work is rarely carried through to completion, often ceasing with the end of the rainy season. By contrast, the CityLab approach offers a more socially, environmentally, and politically sustainable way of mobilizing the community to change mindsets and take initiative independently of government action. Participants therefore encouraged the CSS to continue educating the various stakeholders involved in promoting this sustainable community-based approach to flood-risk management.

\section{Challenges}

The nature of CityLabs as spaces where people from different backgrounds come together inherently makes them difficult to navigate. Other researchers have pointed to challenges ranging from micro-politics to time and budget constraints (Brown-Luthango, 2013; Anderson et al., 2013). The cannot be underestimated and should be factored in when doing this kind of research. The Kumasi CityLab process took place over one year, during which time we were able to build fruitful collaborations with the Sepe-Buokrom assemblyman and other key stakeholders. However, dynamics not uncommon to working in informal settlements (e.g., adhoc and impulsive decisions, and a general lack of adherence to time management principles) greatly affected meeting schedules (e.g., the commencement of the FGDs, as originally planned with the assemblyman). On four separate occasions (both before and then once during the FGDs), the assemblyman had to cancel attendance because of suddenly being called to emergency meetings at the District Assembly. Social gatherings in the community such as funerals also interfered with scheduling, as the assemblyman's position in the community obliges him to attend such functions.

When planning the second SM, we invited the MPs from the Kumasi metropolis who oversee communities deemed flood-prone. Mindful of their busy schedules, 
our invitations and interview questions were sent well ahead of the August meeting, but not a single RSVP was returned. Although we made several efforts to retrieve interview data from the MPs offices in the metropolis, we did not receive a single response.

As per feedback from the first SM documented here, it was suggested that the leadership trio (assemblyman, chief, and MPs), among others, should collaborate to support the Common Vision to help build the community's interest in social responsibility for a CRF for flood-risk management. After the first SM, efforts by the research team to bring these three personages together with other major stakeholders to deliberate on how best to advance a vision of communitybased flood-risk management were made. Unfortunately, the inability to schedule a joint meeting with the chiefs and MPs meant that none of them attended the second (and final) SM in August. Finally, lack of time and the need to meet reporting deadlines prevented the research team from effectively monitoring and evaluating the project, and conducting follow-up initiatives for the project's third 'Closure' phase.

\section{Prospects}

Our reflections as documented in the enablers and challenges earlier conclude that it is indeed possible to achieve a shift in the way we conduct research with communities, such that community members go from being research subjects to equal partners in knowledge production. While there is increasing interest and experiences of such approaches, this remains a novel approach to research in Ghana. However, such a shift requires that the communities and other relevant stakeholders are involved in every stage of the research process.

While the Kumasi CityLab project achieved its goal of creating a space for different stakeholders to engage with community-based responses to flood-risk management and also set the stage for future community-engaged collaborations, it was unsuccessful in bringing the MPs and chiefs together to these engagements. Also, much of our success was based on the cultivation of a long-standing relationship, which may not be possible in every instance.

Other studies have shown the potential of co-production in the field of climate adaptation as a way to influence decision-makers and bridge the gap between research and policy in Africa (Steynor et al., 2016; Ziervogel et al., 2016). This is imperative for meeting both global and local development goals on community resilience for climate adaptation in more structural and sustainable ways.

As part of the project's Closure Phase, our intention was to capture the knowledge shared during the FGDs and SMs in a document to be shared with a wider audience. Although we have not yet been able to complete that document, we have prepared a proposal to expand the CityLab, as per the request from the Kumasi MCE (political leader and head of local government). Meanwhile, a September 2018 exhibition of KNUST College Activities caught the attention of the Ashanti Regional Minister, who then invited the CSS to discuss with him 
the expansion of the work. Additionally, the assemblymen who participated in the second SM have strongly advocated for multi-stakeholder/joint stakeholder engagements with the MPs and chiefs, which would significantly advance the agenda of CRFs for flood-risk management.

As noted, the presiding member commended the CSS research team's proposed approach to tackling flooding problems in Kumasi. He observed that the communitymobilization approach redirects public attention from a focus on demolishing structures to finding risk-management methods that are more socially, environmentally, and politically sustainable. Praising this approach, he suggested that stakeholders start thinking about which measures could be put in place to help manage flooding without focusing solely on demolition. Similarly, the Kumasi MCE and the Metropolitan Director of the National Disaster Management Organization called for this type of engagement to be extended to the rest of Ghana.

The KMA is in the process of executing an MOU with the College of Art and Built Environment/KNUST, which the CSS project discussed here was fundamental in engendering. One major area of interest for this MOU is the creation of a multi-stakeholder platform for the discussion of flood-risk management in Kumasi. Engagements are also ongoing with other local governments, and it is envisaged that the successful uptake of this CityLab's methodology and results will provide the necessary leverage for extending the flood-risk management agenda at the regional and national level.

\section{Conclusion}

Flooding has become a major threat in cities around the world, including in Ghana. While structural measures are critical, nonstructural measures that focus on mitigation and especially adaptation are also essential. This CityLab research engaged a flood-prone community to contribute to the development of a framework for implementing community-led resilience and flood-risk management initiatives.

FGDs and consultative SMs with the community and opinion leaders brought together a wide array of community interest groups, including religious leaders, teachers, civil society groups, community leaders, and representatives from traditional leadership and political parties. The project's objective - to empower and create awareness within the community concerning its own responsibility to develop and act on a common vision for mitigation and coping strategies that can minimize the impacts of flood hazards - was met.

Three key themes emerged from our community engagements: 1) leadership is key, 2) the community/residents must embrace initiatives, and 3) loyalty, commitment, and togetherness are prerequisites for successful community resilience frameworks (CRFs).

The project affirmed the key roles played by the leadership trio (assemblyman, chief, and MP) in mobilizing the community to manage and increase its own resilience to flood risk. It also affirmed that collaboration between this trio is key to developing and implementing a common vision and programme of 
community-based flood-risk management. Additionally, the project found that residents are ready to work towards achieving flood resilience if the leadership trio plays its role.

Through the project, it also emerged that:

To influence the level of community participation in flood-risk management and community-based resilience initiatives, there needs to be an in-depth understanding of the workings of local governance structures, including traditional authorities. Hence, early identification of and engagement with the assemblyman and his office as a key stakeholder is vital. Further:

- Joint meetings of the leadership trio will be fundamental to driving any 'Common Vision', and assemblymen need to advocate harder for better collaboration between the various institutions.

- More public forums and engagement with other stakeholders and chiefs are needed to help drive a change in mindsets about how to adapt to flood-risk through CRFs. Recommendations were made for the Manhyia palace directorate to host such forums and discussions, which, it is expected, would leverage support from the King of the Ashanti Kingdom.

- $\quad$ Political rivalry among the leadership trio (assemblymen, MP, and chief) is a barrier to success, as strong collaboration between that trio is fundamental to mobilizing community support for community adaptation to flood risks. Additionally, nuances in community dynamics (such as diversity along ethnic lines) and apparent tensions between two rival chiefs are also worth noting.

- Given the strategic and close role of the assemblymen to the community, the assemblymen's lack of access to resources to help facilitate engagements is highly problematic, but could be addressed through measures such as the establishment of an 'Assemblymen's Common Fund' for community development projects. It was also suggested that an appeal be made to Parliament to review the allocation and use of the District Assembly Common Fund.

- The CityLab approach diverts attention from the 'populist approach' used by government functionaries, and offers a more socially, environmentally, and politically sustainable way of mobilizing the community to change mindsets and take initiative independently of government action.

- Public interest in the project's stakeholder engagements was remarkable, with the project attracting a great deal of publicity in radio, television, and print media.

\section{Future research and practical actions}

The Kumasi CityLab project has demonstrated both the importance of adopting a community resilience approach for flood-risk management in Ghana, and the readiness of stakeholders to assume their respective roles. It also has demonstrated the benefits of knowledge co-production among various stakeholders in flood-risk management in Ghana, and has led to CRF development assuming a 
national dimension, with a number of other local government areas requesting the CSS to engage communities within their jurisdictions by holding similar forums.

Reflecting on our findings, the research team suggested that the House of Parliament play a lead role in making community-based flood-risk management part of the national agenda, by proposing a bill for a Flood Control Act in Ghana. Flood risk in Ghana by all accounts is a grave national threat, and in June 2019, the House of Parliament requested the Minister of Works and Housing to provide a national plan for addressing floods in the country (Citifm Online, 2018). Such legislation not only would help make this issue a national priority, but also would assist in the implementation and enforcement of an integrated flood-risk management framework, including aspects relating to community resilience. All of this would support community members in learning what they can do for themselves regarding flood-resilient construction and adaptation, without flouting the law. Meanwhile the CSS continues to work to create a broader platform for this national conversation on engendering a community-based flood-risk management agenda. For example, on 22 May 2019, we were invited by a local FM station to share lessons on the Kumasi CityLab project, with the resulting sound bite aired the following day on Ghana's most popular radio station, Joy $99.7 \mathrm{FM} / \mathrm{Luv} 99.5$ of the Multimedia Group Ltd.

\section{Notes}

1 As of June 2019, new regions have been created out of the original ten, meaning Ghana now has 16 administrative regions.

2 The KMA was formerly comprised of nine sub-metros, but due to reforms in the governance structure within the last couple of years, it now comprises five sub-metros, including Manhyia sub-metro.

3 Opinion leaders are leaders of interest groups in the community who command respect and are influential in decision-making within the community.

4 The assemblyman and unit committee members will be referred to collectively as assemblyman/assemblymen. Assemblymen can be either men or women, but in the case of Sepe-Buokrom, the assemblyman is male.

5 The assemblyman is required to regularly brief his electorate on the general decisions of the Assembly and its Executive Committees, including the actions taken to solve problems raised by residents in his electoral area.

6 Under Function 3(e) of the District Assemblies in the Local Government Act 462.

$7 \mathrm{DACF}$ is a Development Facility allocated to MMDAs to supplement their revenue base to enable them implement planned projects and programmes in their respective communities (Ankamah, 2012). It is backed by Act 455, 2003 of the 1992 Constitution of Ghana, and Parliament annually makes a provision for its allocation. Members of Parliament are given a share of the fund to undertake development projects in their respective constituencies.

8 In the Ashanti region of Ghana in particular, chiefs are custodians of the land, a resource that is at the centre of infrastructure development and its associated floods in many parts of Kumasi.

9 Manhyia as used here refers to the overlord Chief Palace for the Ashanti Kingdom in Ghana. All chiefs in the Ashanti region (including Kumasi and the study area) owe allegiance to the occupant of Manhyia, who is the King of the Ashantis. There is a 
suggestion that if the overlord's support is brought into the picture, it would provide much-needed attention for chiefs (in the metropolis in particular) to embrace this flood-risk management initiative.

10 The presiding member is an assemblyman elected by the house to lead the District Assembly, and also acts as the Chairman of the general assembly.

\section{References}

Abdallah, K. (2011 September 13). Assembly members deserve monthly salary. Rumnet [online]. Retrieved: https://rumnetwordpress.com/2011/09/13/assembly-members-des erve-monthly-salary/

Adger, W.N., Agrawala, S. \& Mirza, M.M.Q. (2007). Assessment of adaptation practices, options, constraints, and capacity. In: Parry, M.L., Canziani, O.F. \& Palutikof, J.P. (Eds.), Climate change 2007: impacts, adaptation and vulnerability. Contribution of working group ii to the fourth assessment report of the intergovernmental panel on climate change. Cambridge: Cambridge University Press, pp. 717-743.

Afriyie, K., Ganle, J.K. \& Santos, E. (2018). The floods came and we lost everything: weather extremes and households' asset vulnerability and adaptation in rural Ghana. Climate and Development, 10(3), pp. 259-274. DOI: https://doi.org/10.1080/17565529.2017.1291403

Ahadzie, D.K., Dinye, I., Dinye, R.D. \& Proverbs, D.G. (2016). Flood risk perception, coping and management in two vulnerable communities in Kumasi, Ghana. International Journal of Safety and Security Engineering, 6(3), pp. 538-549. DOI: https://doi. org/10.2495/SAFE-V6-N3-538-549/009

Ahadzie, D.K. \& Proverbs, D.G. (2011). Emerging issues in the management of floods in Ghana. International Journal of Safety and Security Engineering, 1(2), pp. 182-192. DOI: https://doi.org/10.2495/SAFE-V1-N2-182-192

Akaateba, M.A., Huang, H. \& Adumpo, E.A. (2018). Between co-production and institutional hybridity in land delivery: insights from local planning practice in peri-urban Tamale, Ghana. Land Use Policy, 72, pp. 215-226.

Anderson, P.M.L., Brown-Luthango, M., Cartwright, A., Farouk, I. \& Smit, W. (2013). Brokering communities of knowledge and practice: reflections on the African centre for cities, citylab programme. Cities, 32, pp. 1-10. DOI: https://doi.org/10.1016/j. cities.2013.02.002

Ankamah, S.S. (2012). The politics of fiscal decentralization in Ghana: an overview of the fundamentals. Public Administration Research, 1(1), p. 33.

Asamoah, R.O., Nelson, I.D., Twumasi-Ampofo, K., Ayeh, B.S., Offei-Nyako, K. \& Ankrah, J.S. (2016). Invasion of wetlands in Kumasi by informal economic activities and consequences for urban management. Planning, 1(1), pp. 11-16. DOI: https://doi. org/10.11648/j.urp.20160101.13

Asumadu-Sarkodie, S., Owusu, P.A. \& Rufangura, P. (2015). Impact analysis of flood in Accra, Ghana. Advances in Applied Science Research, 6(9), pp. 53-78. DOI: https://doi. org/10.6084/M9.FIGSHARE.3381460

Atanga, R.A. (2020). The role of local community leaders in flood disaster risk management strategy making in Accra. International Journal of Disaster Risk Reduction, 43. DOI: https://doi.org/10.1016/j.ijdrr.2019.101358

AURI. (2014 February 18-19). Institutional models of co-production in the African city. Proceedings of the 2nd African Urban Research Initiative (AURI) conference. Nairobi, Kenya. 
Bender, G. (2008 March). Exploring conceptual models for community engagement at higher education institutions in South Africa. Perspectives in Education, 26, pp. 81-95.

Brown-Luthango, M. (2013). Community-university engagement: the Philippi citylab in Cape Town and the challenge of collaboration across boundaries. Higher Education, 65(3), pp. 309-324.

Chong, N.O., Kamarudin, K.H. \& Abd Wahid, S.N. (2018). Framework considerations for community resilient towards disaster in Malaysia. Procedia Engineering, 212, pp. 165172. DOI: https://doi.org/10.1016/j.proeng.2018.01.022

Chirisa, I., Bandauko, E., Mazhindu, E., Kwangwama, N.A. \& Chikowore, G. (2016). Building resilient infrastructure in the face of climate change in African cities: scope, potentiality and challenges. Development Southern Africa, 33(1), pp. 113-127. DOI: https://doi.org/10.1080/0376835X.2015.1113122

Citifm Online. (2018). Minority summons Atta-Akyea over flooding fears [online]. Retrieved: http://citifmonline.com/2018/02/minority-summons-atta-akyea-floodingfears/ [Accessed on 24 January 2020]

Cutter, S.L., Barnes, L., Berry, M., Burton, C., Evans, E., Tate, E. \& Webb, J. (2008). A place-based model for understanding community resilience to natural disasters. Global Environmental Change, 18, pp. 598-606. DOI: https://doi.org/10.1016/j. gloenvcha.2008.07.013

Dollah, S., Abduh, A. \& Rosmaladewi, R. (2017). Benefits and drawbacks of NVivo QSR application. In: Advances in social science, education and humanities research (ASSEHR). Proceedings of the 2nd International Conference on Education, Science, and Technology (ICEST), vol. 149, pp. 61-63. Retrieved: https://www.researchgate.net/ publication/320893973_Benefits_and_Drawbacks_of_NVivo_QSR_Application

Douglas, I., Alam, K., Maghenda, M., Mcdonnell, Y., McLean, L. \& Campbell, J. (2008). Unjust waters: climate change, flooding and the urban poor in Africa. Environment and Urbanization, 20(1), pp. 187-205.

Filho, W.L., Balogun, A., Ayal, D.Y., Bethurem, E.M., Murambadoro, M., Mambo, J., Taddese, H., Tefera, G.W., Nagy, G.J., Fudjumdjum, H. \& Mugabe, P. (2018). Strengthening climate change adaptation capacity in Africa - case studies from six major African cities and policy implications. Environmental Science \& Policy, 86, pp. 29-37. DOI: https:// doi.org/10.1016/j.envsci.2018.05.004

Floodlist. (2018). Ghana - devastation floods hit Accra again. Floodlist [online]. Retrieved: http://floodlist.com/africa/ghana-floods-accra-june-2018 [Accessed on 24 January 2020]

Floodlist. (2019). Ghana - floods cause devastation in upper East region. Floodlist [online]. Retrieved: http://floodlist.com/africa/ghana-floods-upper-east-region-october-2019 [Accessed on 24 January 2020]

Frimpong, A. (2014). Perennial floods in the Accra Metropolis: Dissecting the causes and possible solutions. African Social Science Review, 6(1), pp. 1-14.

Ghana Statistical Service. (2012). Ghana population and housing census 2010 report. Accra: Ghana Statistical Service.

Government of Ghana (GoG). (2015). Local government legislative instrument 2223. Accra: Ministry of Local Government and Rural Development.

Government of Ghana (GoG). (2016). Local governance act of 2016, Act 936. Accra: Ministry of Local Government and Rural Development.

Graphic Online. (2018). Give Assembly members 5\% of common fund. Graphic Online [online]. Retrieved: www.graphic.com.gh/news/politics/give-assembly-men [Accessed on 12 November 2018] 
Huong, H.T.L. \& Pathirana, A. (2013). Urbanization and climate change impacts on future urban flooding in Can Tho city, Vietnam. Hydrology and Earth System Sciences, 17(1), pp. 379-394.

International Federation of Red Cross and Crescent Societies (IFRC). (2015). Emergency plan of action (EPoA) - Ghana: floods. Retrieved: https://reliefweb.int/report/ghana/ ghana-floods-emergency-plan-action-epoa-mdrgh011

International Federation of Red Cross and Crescent Societies (IFRC). (2017). Emergency plan of action final report - Ghana: floods. Retrieved: https://reliefweb.int/sites/ reliefweb.int/files/resources/MDRGH014dfr.pdf

IPCC. (2007). Climate change 2007: the physical science basis. Contribution of working group I to the fourth assessment report of the intergovernmental panel on climate change [Solomon, S., Qin, D., Manning, M., Chen, Z., Marquis, M., Averyt, K.B., Tignor, M. \& Miller, H.L. (Eds.).]. Cambridge and New York: Cambridge University Press.

IPCC. (2013). Summary for policymakers. In: Stocker, T.F., Qin, D., Plattner, G.K., Tignor, M., Allen, S.K., Boschung, J., Nauels, A., Xia, Y., Bex, V. \& Midgley, P.M. (Eds.), Climate change 2013: the physical science basis. Contribution of working group I to the fifth assessment report of the intergovernmental panel on climate change. Cambridge and New York: Cambridge University Press.

IPCC. (2018). Climate report [Masson-Delmotte, V., Zhai, P., Pörtner, H.O., Roberts, D., Skea, J., Shukla, P.R., Pirani, A., Moufouma-Okia, W., Péan, C., Pidcock, R., Connors, S., Matthews, J.B.R., Chen, Y., Zhou, X., Gomis, M.I., Lonnoy, E., Maycock, T., Tignor, M. \& Waterfield, T. (Eds.).]. Geneva: World Meteorological Organization.

Jagers, S.C. \& Duus-Otterström, G. (2008). Dual climate change responsibility: on moral divergences between mitigation and adaptation. Environmental Politics, 17(4), pp. 576-591.

Jha, A.K., Bloch, R. \& Lamond, J. (2012). Cities and flooding: a guide to integrated urban flood risk management for the 21st century. Washington, DC: World Bank.

Jones, L. \& Boyd, E. (2011). Exploring social barriers to adaptation: insights from Western Nepal. Global Environmental Change, 21(4), pp. 1262-1274.

Kellens, W., Terpstra, T. \& De Maeyer, P. (2013). Perception and communication of flood risks: a systematic review of empirical research. Risk Analysis, 33(1), pp. 24-49.

Kruse, S., Abeling, T., Deeming, H., Fordham, M., Forrester, J., Jülich, S., Karanci, A.N., Kuhlicke, C., Pelling, M., Pedoth, L. \& Schneiderbauer, S. (2017). Conceptualizing community resilience to natural hazards - the emBRACE framework. Natural Hazards Earth System Sciences, 17, pp. 2321-2333. DOI: https://doi.org/10.5194/nhess-17-2321-2017

Local Government Act 462. (1993). Local government service - Ghana. Retrieved: https:// lgs.gov.gh/index.php/laws-acts-and-legislative-instruments/

Lohmann, S., Heimerl, F., Bopp, F., Burch, M. \& Ertl, T. (2015 July). Concentri cloud: word cloud visualization for multiple text documents. Information visualisation (iV), 19th International Conference on Information Visualisation, Barcelona, Spain, pp. 114120. DOI: https://doi.org/10.1109/iV.2015.30

Lwasa, S. (2010). Adapting urban areas in Africa to climate change: the case of Kampala. Current Opinion in Environmental Sustainability, 2(3), pp. 166-171. DOI: https://doi. org/10.1016/j.cosust.2010.06.009

Magadza, C.H.D. (2000). Climate change impacts and human settlements in Africa: prospects for adaptation. Environmental Monitoring and Assessment, 61(1), pp. 193-205.

Mail\&Guardian. (2018 October 11). The IPCC's latest climate report on 1.5 holds implications for African Countries. Mail\&Guardian [online]. Retrieved: https://mg.co.za/ article/2018-10-11-the-UN Climate Reports-latest-climate-report-on-15c-holds-implica tions-for-african-countries/ 
Mangai, M. \& De Vries, M. (2018). Co-production as deep engagement: improving and sustaining access to clean water in Ghana and Nigeria. International Journal of Public Sector Management, 31(1), pp. 81-96.

McCusker, B. \& Carr, E.R. (2006). The co-production of livelihoods and land use change: case studies from South Africa and Ghana. Geoforum, 37(5), pp. 790-804.

McNaught, C. \& Lam, P. (2010). Using Wordle as a supplementary research tool. The Qualitative Report, 15(3), pp. 630-643.

Mertz, O., Halsnæs, K., Olesen, J.E. \& Rasmussen, K. (2009). Adaptation to climate change in developing countries. Environmental Management, 43(5), pp. 743-752.

Muller, M. (2007). Adapting to climate change: water management for urban resilience. Environment and Urbanization, 19(1), pp. 99-113.

Mullins, A. \& Soetanto, R. (2011). Enhancing community resilience to flooding through social responsibility. International Journal of Safety and Security Engineering, 1(2), pp. $115-125$.

Nations Online. (2018). Political map of West Africa. Nations Online Project [online]. Retrieved: www.nationsonline.org/oneworld/map/west-africa-map.htm [Accessed on 17 December 2018]

Niehm, L.S., Swinney, J. \& Miller, N.J. (2008). Community social responsibility and its consequences for family business performance. Journal of Small Business Management, 46(3), pp. 331-350.

Nkrumah, A.A. (2016). Ghana flood league table. Ahaspora [online]. Retrieved: www. ahaspora.com/ghana-floods-league-table-2016-guest-blog-the-green-ghanaian/

Norris, F.H., Stevens, S.P., Pfefferbaum, B., Wyche, K.F. \& Pfefferbaum, R.L. (2008). Community resilience as a metaphor, theory, set of capacities, and strategy for disaster readiness. American Journal of Community Psychology, 41(1-2), pp. 127-150. DOI: https://doi.org/10.1007/s10464-007-9156-6

Owusu-Ansah, J.K. (2016). The influences of land use and sanitation infrastructure on flooding in Kumasi, Ghana. Geojournal of Spatially Integrated Social Science and Humanities, 81(4), pp. 555-570.

Parnell, S. (2016). Defining a global urban development agenda. World Development, 78, pp. 529-540. DOI: https://doi.org/10.1016/j.worlddev.2015.10.028

Pasquali, M. (2007). Video in science: protocol videos: the implications for research and society. EMBO Reports, 8(8), pp. 712-716. DOI: https://dx.doi.org/10.1038\%2Fsj. embor.7401037

Patel, Z., Greyling, S., Parnell, S. \& Price, G. (2015). Co-producing urban knowledge: experimenting with alternatives to best practice for Cape Town, South Africa. International Development Planning Review, 37(2), pp. 187-203.

Pohl, C., Rist, S., Zimmermann, A., Fry, P., Gurung, G.S., Schneider, F., Speranza, C.I., Kiteme, B., Boillat, S., Serrano, E. \& Hadorn, G.H. (2010). Researchers' roles in knowledge co-production: experience from sustainability research in Kenya, Switzerland, Bolivia and Nepal. Science and Public Policy, 37(4), pp. 267-281.

Proverbs, D. (2011). Editorial. International Journal of Safety and Security Engineering, 1(2), pp. iii-iv.

Proverbs, D. \& Lamond, J. (2017). Flood resilient construction and adaptation of buildings. Natural Hazards Science, 10(2), pp. 1-3.

Renschler, C., Reinhorn, A., Arendt, L. \& Cimellaro, G. (2011 May 25-28). The P.E.O.P.L.E.S. resilience framework: a conceptual approach to quantify community resilience [Papadrakakis, M., Fragiadakis, M. \& Plevris, V. (Eds.)]. 3rd ECCOMAS Thematic Conference on Computational Methods in Structural Dynamics and Earthquake Engineering, Corfu, Greece. DOI: https://doi.org/10.13140/RG.2.1.3355.1767 


\section{2}

Divine Ahadzie et al.

Rodriguez, R.S., Ürge-Vorsatz, D. \& Barau, A.S. (2018). Sustainable development goals and climate change adaptation in cities. Nature Climate Change, 8, pp. 181-183.

Serdeczny, O., Adams, S., Baarsch, F., Coumou, D., Robinson, A., Hare, B., Schaeffer, M., Perrette, M. \& Reinhardt, J. (2015). Climate change impacts in sub-Saharan Africa: from physical changes to their social repercussions. Regional Environmental Change, 15(8). DOI: https://doi.org/10.1007/s10113-015-0910-2

Shafer, W.E., Fukukawa, K. \& Lee, G.M. (2007). Values and the perceived importance of ethics and social responsibility: the US versus China. Journal of Business Ethics, 70(3), pp. 265-284.

Steynor, A., Padgham, J., Jack, C., Hewitson, B. \& Lennard, C. (2016). Co-exploratory climate risk workshops: experiences from urban Africa. Climate Risk Management,13, pp. $95-102$.

Sylla, M., Nikiema, M., Gibba, P., Kebe, I., Klutse, N. \& Browne, A. (2016). Climate change over West Africa: recent trends and future projections. In: Yaro, J.A. \& Hesselberg, J. (Eds.), Adaptation to climate change and variability in rural West Africa, pp. 25-40. DOI: https://doi.org/10.1038/s41598-018-32736-0

Terumoto, K. (2006). Issues and attitudes of local government officials for flood risk management. In: Ikeda, S., Fukuzono, T. \& Sato, T. (Eds.), A better integrated management of disaster risks: toward resilient society to emerging disaster risks in mega-cities. Tokyo: TERRAPUB and NIED, pp. 165-176.

van Vuuren, D.P., Isaac, M., Kundzewicz, Z.W., Arnell, N., Barker, T., Criqui, P., Berkhout, F., Hilderink, H., Hinkel, J., Hof, A. \& Kitous, A. (2011). The use of scenarios as the basis for combined assessment of climate change mitigation and adaptation. Global Environmental Change, 21(2), pp. 575-591.

Wilby, R.L. \& Keenan, R. (2012). Adapting to flood risk under climate change. Progress Physical Geography, 36(3), pp. 348-378.

Wood, M., Kovacs, D., Bostrom, A., Bridges, T. \& Linkov, I. (2012). Flood risk management: US army corps of engineers and layperson perceptions. Risk Analysis: An International Journal, 32(8), pp. 1349-1368.

Zamawe, F.C. (2015). The implication of using NVivo software in qualitative data analysis: evidence based reflections. Malawi Medical Journal, 27(1), pp. 13-15.

Ziervogel, G., van Garderen, E.A. \& Price, P. (2016). Strengthening the knowledge policy interface through co-production of a climate adaptation plan: leveraging opportunities in Bergrivier municipality, South Africa. Environment and Urbanization, 28(2), pp. $455-474$. 